UDC 316.7:331.53

http://doi.org/10.21272/mmi.2019.3-16

\author{
JEL Classification: M11, M31, M37
}

\author{
Neringa Vilkaite-Vaitone, \\ D.Sc., Vilnius Gediminas Technical University, Lithuania \\ Ugne Lukaite, \\ Vilnius University, Lithuania
}

\title{
COMPANY IMAGE IN SOCIAL NETWORK AS PREDICTOR OF INTENTION TO APPLY FOR A JOB POSITION
}

\begin{abstract}
This paper summarizes the arguments and counterarguments within the scientific discussion on the issue of employer attractiveness on social networks, organizational image impact upon intentions to apply for a job position in banking industry. The main purpose of the research is to theoretically and empirically evaluate the impact of attractive workplace communications on social networks and image of a bank as an employer upon intentions to apply for a job position. Systematization of literary sources and approaches for solving the research problem indicates that there exist sufficient scientific background to expect a positive impact of workplace attractiveness on the image of employer. Usage of social media is also supposed to have a positive impact on the image, while the image might be a predictor of intentions to apply for a job. The relevance of the decision of this scientific problem is that social media has a huge potential to strengthen employer's image, however, it also might destroy a carefully formed employer's image. Such a potential stresses the role of banks' communications on social network for building efficient employer image. A questionnaire research of students is carried out in Lithuania. The paper presents the results of an empirical analysis, which showed that job seekers in a labour market behave similarly to consumers in a marketplace. Banks should put efforts in order to present themselves as attractive working places on social networks in order to form a favourable employer's image and encourage job seekers to apply for positions. Results of this study indicate that usage of social networks for the formation of image of employer can be a helpful tool. This is important because there are clear links between workplace attractiveness, usage of social networks and image of an employer. The latter construct is positively related to intentions to apply for a job. The results of the research can be useful for commercial banks. This study provides banks with useful insights of the factors that determine their image in labour market. Such insights give banks a perceptible information of how to become more attractive in labour market with the help of communications on social networks.
\end{abstract}

Keywords: employer attractiveness, employer branding, social networks, organizational image, intention to apply for a job, banking industry.

Introduction. Organizations that create a favourable, unique brand image in customers' minds increase the probability that customers will choose their products over the alternatives (Collins and Stevens, 2002). Similar processes might be identified in case of people looking for a job. Nowadays, when there is a lack of potential, talented employees and qualified labour force, companies need to pay attention not only how to perceive and attract needed job seekers, but to understanding what makes their organization more attractive for the employees as well. Moreover, for the business leaders, it is important not only to attract the best workers, but also and how to maintain them, also try to achieve lesser changes of the workers, so really big attention should be designated for the image of the employer brand. Organizations that have a strong brand identity might get a priority over those that have weak or negative identity.

The image of employer is determined by a huge variety of factors: organizational communication, identity, culture, structure, market identity, strategy, people, salary, career opportunities, work characteristics, employer's reputation (Marcus and Schuler, 2004; Cable and Yu, 2006; Knox and Freeman, 2006; Melewar and Karaosmanoglu, 2006; Cretu and Brodie, 2007; Tuzuner and Yuksel, 2009; Caligiuri et al., 2010; Bondarouk et al., 2012). One of them, i. e. attractive workplace communication, is of particular importance. According to I. Figurska and E. Matuska (2013), when

Cite as: Vilkaite-Vaitone, N., Lukaite, U. (2019). Employer Attractiveness on Social Networks and Organizational Image as Predictors of Intentions to Apply for a Job Position. Marketing and Management of Innovations, 3, 209-222. http://doi.org/10.21272/mmi.2019.3-16 
organization seems to be attractive place to work, its image becomes highly rated on the market and it becomes employer of choice. The ability to attract the most valuable and talented employees' results in an increase of labour productivity, innovativeness and it consequently leads to the strengthened competitive position (Figurska and Matuska, 2013). Banks undoubtedly operate in a highly competitive market, so such a path for increasing competitiveness might be prosperous. One way to attract talented and valuable employees is via internet. During the last decade corporate websites have gained popularity. According to C. Priyadarshini et al. (2017, p. 969), «the effectiveness of corporate website facilitates the companies in differentiating themselves from their competitors, which in turn leads to overall organizational attractiveness». However, since late 2007 the usage of corporate websites for the attraction of employees has decreased due to the shift towards social networks (Priyadarshini et al., 2017). According to P. Kissel and M. Buttgen (2015, p. 755), «the rise of social media gives employers a new communication channel for delivering job-related information, strengthening their image and entering into a dialog with potential candidates early in their employment choice processes». The growth of popularity of social media creates challenges for creation of image of the employer, i. e. bank. In reference to I. Figurska and E. Matuska (2013, p. 49), social media becomes «a dominant factor shaping company's image in society». Social media has a huge potential to strengthen employer's image, however, it also might destroy a carefully formed employer's image. Such a potential stresses the role of banks' communications on social network for building efficient employer image.

Prior studies of image of employer have examined employer attractiveness from a generational perspective (Reis and Braga, 2016), in a multicultural context (Eger et al., 2019), employer brand image in the service industry (Knox and Freeman, 2006), employer brand image as predictor of employee satisfaction, affective commitment and turnover (Priyadarshi, 2011), employer attractiveness and the use of social media (Sivertzen et al., 2013), etc. There is limited amount of research that examines how attractive workplace communications impact the image of employer (Highhouse et al., 2003), however none of them concentrated particularly on communications on social networks in banking industry.

Object of the research is the impact that attractive workplace communications on social networks and organizational image have upon the willingness to apply for a job in a commercial bank. The main aim is to theoretically and empirically evaluate the impact of attractive workplace communications on social networks and image of a bank as an employer upon intentions to apply for a job position.

Literature Review. This section of the paper starts with the revelation of the concept of workplace attractiveness and its elements. Employer attractiveness «refers to the benefits that potential employees envisage they could get by working in a particular company» (Reis and Braga, 2016, p. 105). A very similar definition is suggested by Eger et al. (2019). Authors suggest treating employer attractiveness as «the benefits potential employees anticipate from working for a specific organization» (Eger et al., 2019, p. 523).

G. G. Reis and B. M. Braga (2016) emphasize that attractiveness of a workplace differs from the attraction of candidates during the process of recruitment. During the recruitment stage organization seeks to attract potential job seekers for available positions at a particular time, while attractiveness of organization as a workplace has to be continuously worked on. This endeavour is supposed to make the company recognized as attractive employer in the labour market and in turn to facilitate recruitment.

Attractiveness of an organization serves as both an external and an internal level. Organizational attractiveness fosters organizational growth in the future. In the opinion of D. Gomes and J. Neves (2011), organizational attractiveness is measured by new job seekers and experienced job seekers depending on the company's prestige, but in both cases the employer's brand serves as the main feature of the organization in order to attract new ones employees. T. T. Jiang and P. Iles (2011) have defined organizational attractiveness as the power that encourages potential employees to pay attention to the employer's brand, while existing ones staying for longer periods of time, thus improving your 

Intentions to Apply for a Job Position

image even more. T. T. Jiang and P. Iles (2011) divided organizational appeal into two categories, one is known as an internal attractiveness of the organization, and the second one is called the external organization's attractiveness, and has proven that organizations as employer brand / exclusivity and talent management are related to organizational attractiveness. L. Moroko and M. D. Uncles (2008) also claim that attractiveness is named as the main element of the success of the employer's brand. Therefore, the employer's concept of attractiveness has been analysed both internally and externally in the context of elements as a means of maintaining and attracting employees (Pingle and Sharma, 2013). Indoor attractiveness expresses the perception of existing employees, and the external attractiveness means the perception of external applicants (Jian and Iles, 2011). In other words, the intrinsic attractiveness of the employer is the degree of attractiveness among existing employees of the company. Exterior attractiveness is attractive to the eyes of future employees (Pingle and Sharma, 2013). Thus, we can assume that what makes an enterprise attractive within it (employer's attractiveness), it can also include both internal and external collaboration that makes the company as an attractive workplace.

Although each organization would like to be attractive to employers for potential and existing workers, the literature does not clearly indicate the elements that define employer attractiveness.

Analysis of workplace attractiveness lets to define this concept as benefits that are envisage of potential and current employees related to working in a particular organization. The conception involves potential and current employees as attractiveness of an organization serves both external and internal level.

Social network is an important channel for attractive workplace communications. In each community people create their own social networks. A social network is a social structure that focuses on individuals or organizations interacting with common values, for example, ideas, interests, financial exchanges, friendship or even conflict, and so on. In every space, whether professional or family, we create our own weak or strong social networks. If the links between social networking elements are strong, they can affect many things, for example, a good employee who has established a strong social network, has left the organization and takes that network with him, causing great losses to the organization, and that can really affect company's attractiveness as an employer.

It is really important to emphasize the difference between social networks and social media. A. M. Sivertzen et al. (2013, p. 475) suggest to define social network sites as services based on web that let «individuals to construct a public or semi-public profile within a bounded system, articulate a list of other users with whom they share a connection, and view and traverse their list of connections and those made by others within the system». However, social media is online content that people have created with easy accessible technologies that can allow usually creating, place and disseminate information. So one can assume that the usage of social networks is really important when organization seeks to attract employees.

A considerable growth of social media (in terms of social networking sites, users) gives implications for transformations in businesses. These changes encourage companies to engage in a huge variety of activities in social networks. One of them is social media recruitment. C. Priyadarshini et al. (2017, p. 971) define this term as the «use of social media to communicate about the job openings and attracting the potential candidate to apply for a given job position».

C. Priyadarshini et al. (2017) compared social networks to internet sites and found out that corporate websites usually provide general background information about the company, while social networks provide a variety of options for attraction of labour force. For example, in its «Facebook» profile a company can create and publish calendar of events for recruitment, job interviews, etc. It is also worth to mention that a «Facebook» pages are free (if advertising services are not bought), while companies experience costs related to updating and maintaining of corporate websites. Results of empirical 
research conducted by C. Priyadarshini et al. (2017) have shown that potential job seekers prefer social networks because: they provide a relevant and necessary information; navigation is usable and user friendly; public information lets to check if there exists a fit between organization and interests of job seeker; communication in social networks is reliable and speedy; they ensure cost efficiency in recruiting employees; create value for employees.

Results of the research that was accomplished in 2012 has shown that $73 \%$ of employers have successfully hired an employer through social networks (Priyadarshini et al., 2017). It can be reasonably expected that after 7 years this share is considerably larger. It means that «social media platforms are no longer restricted to recreation purposes, but are extended to serve the organizations as an appropriate cyberspace to promote and connect themselves with current and prospective employees » (Priyadarshini et al., 2017, p. 970).

It can be stated that social network is a social structure that focuses on individuals or organizations interacting with common values, for example, ideas, interests, financial exchanges, friendship or even conflict, and so on. Under the conditions of tremendous development of internet, online social networks became an important channel for the recruitment of employees.

It is important for every company to create an appropriate and attractive image of the brand in the market which they operate. However, the company is visible not only as a seller of goods or services, as a lessor or a lender but also as an employer. In search of new talents, the unique candidates are strongly influenced by the image of the company as an employer. All companies have an image in the eyes of the candidates, regardless of whether they create it themselves or not. According to the author, the image of the employer can be described as one of the main marketing principles that apply to human resource activities based on current and potential employees (Edwards, 2010). Understanding the benefits of a good employer image strategy can be the first step towards becoming an attractive employer, so it is really necessary for employer to have a good image of the employer. It is important to create an organization's image nowadays, because it is described as important strategic management and marketing goal.

An accepted model of associative memory helps to understand dimensions of employer image. In associative memory models memory is postulated to store the information in the form of nodes. Nodes are treated as specific bits of information. They «are connected via links that vary I strength» (Collins and Stevens, 2002, p. 6). Recall or activation of a node triggers other nodes respectively to the strength of the link. In such a way related information becomes usable. In reference to this conceptualization image of employer is treated as having two dimensions: the node itself and awareness of employer. These dimensions have links with associated feelings, related information, knowledge of employer (Collins and Stevens, 2002).

According to S. Knox and C. Freeman (2006), A. E. Cretu and R. J. Brodie (2007), the image of the organization is determined by various factors. According to T. C. Melewar and E. Karaosmanoglu (2006) organizations image is influenced by: organizational communication, identity, culture, structure, market identity, strategy. Meanwhile P. Caligiuri et al. (2010) viewed the image on the basis of four key elements: people and culture, salary and career opportunities, work characteristics and the employer's reputation.

In this section image was defined as the result of a transaction where marketing unit's emitted signals are sent to receptor and organized into a specific mental perception. In case of employment receptor is a potential of current employee of the organization. It was found out that various factors, i. e. organizational communication, identity, culture, structure, market identity, strategy, people, salary, career opportunities, work characteristics, employer's reputation determine the image of employer.

There are several studies that have demonstrated relations between attractive workplace communications and the image of employer (Knox and Freeman, 2006; Figurska and Matuska, 2013; 
Sivertzen et al., 2013; Priyadarshini et al., 2017). Analysis of the studies lets to formulate research model (Figure 1).

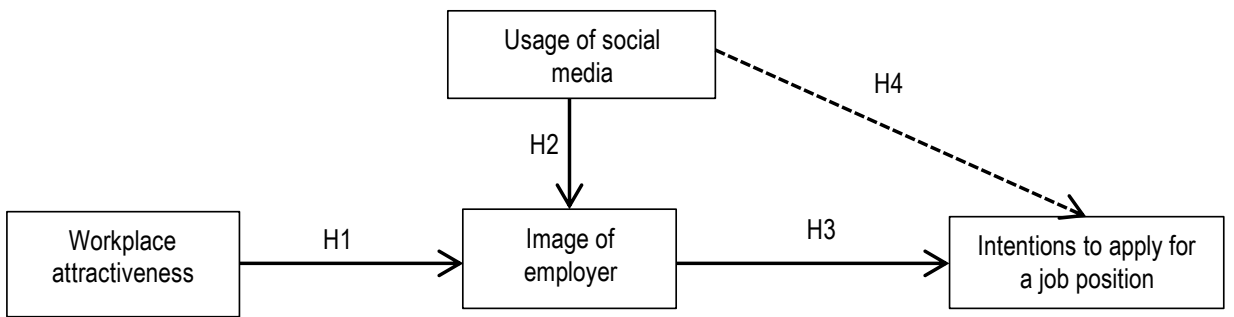

Figure 1. Relations between attractive workplace communications, usage of social media, image of employer and intentions to apply for a job position

Source: developed by the authors.

The employer's attractiveness in literature is often related to the employer's brand exclusivity, it means that the attractiveness of an employer is often understood as a common employer's brand image predecessor (Berthon et al., 2005). According to P. Berthon et al. (2005), it can be said that the more attractive an organization is, the stronger can be the employer's brand. Arachige and Robertson (2013) state that employer attractiveness is essential in order to create an attractive employer's brand when recruiting and retaining employees. A. Celani and P. Singh (2011) pointing out the attractiveness of the organization added that the employer brand / exclusivity actually makes the organization more attractive to jobseekers, therefore, the organization needs to put less effort into attracting talent. Attractiveness stimulate potential candidates to focus on an employer brand (Eger et al., 2019). Theoretical analysis lets to state that the more attractive place is for employees, the better image it possesses (Berthon et al., 2005; Celani and Singh, 2011; Arachige and Robertson, 2013; Figurska and Matuska, 2013). It means that there exists a possibility that workplace attractiveness has a positive impact upon image of employer. These insights let to formulate the following hypothesis:

H1: potential employees' perception of workplace attractiveness is positively related with the perception of good image of employer.

C. Priyadarshini et al. (2017) provided useful insights in the field of using social media as a source for the formation of employer attractiveness. Authors conducted focus group interviews and found out that human resource managers should use social media in order to create a favourable image of employer. Social media might be a valuable source to enhance employer's image, because they enable employers to maintain long term conversation and constant connectivity with a potential employee (Priyadarshini et al., 2017). Apart from this, in social networks employer image can be enhanced by electronic word-of-mouth endorsements. C. Priyadarshini et al. (2017) state that people trust social media. Trust also has a potential to enhance the image of employer.

Social networks are a significant source for the spread of information about employer's attractiveness (Priyadarshini et al., 2017). It means that social networks can be widely used in enhancing image of employer. In reference to these presumptions the following hypothesis is formulated:

H2: potential employees' perception of employers' usage of social networks is positively related with a good image of employer.

Organization that possesses a highly rated image has a huge potential to attract the most talented and valuable employees (Figurska and Matuska, 2013). S. Knox and C. Freeman (2006) confirm that image of employer quite significantly is able to predict primary decisions made by new recruits regarding their employers. Image of employer has a positive influence upon applicant's behaviours, perceptions or organizational attributes. Authors have found that there exist moderate relationship between image of 
employer and the likelihood that potential employee will submit an application to the firm $(r=0.440$; $p=0.000$ ). It means that there exists sufficient scientific background of relationships between image of employer and potential employees' intentions to apply for a job. Such intentions can be explained by the theory of planned behaviour (Ajzen, 1991; Mathieson, 1991; Ajzen, 2002). This theory emphasizes that «intentions to perform behaviours of different kinds can be predicted with high accuracy from attitudes toward the behaviour, subjective norms, and perceived behavioural control; and these intentions, together with perceptions of behavioural control, account for considerable variance in actual behaviour» (Ajzen, 1991). Therefore, it is reasonable to expect that a person who has intentions to apply for a job will actually apply.

Analysis of scientific literature has shown that image of employer has a positive influence upon applicant's behaviours, perceptions or organizational attributes (Knox and Freeman, 2006; Figurska and Matuska, 2013). Therefore, the following hypothesis needs to be considered:

H3: good image of employer is positively related with potential employees' intentions to apply for a job.

The significance and extremely wide usage of social networks nowadays lets to presume that usage of social networks might moderate the relationship between image of the employer and potential employees' intention for a job. These insights let to form the following hypothesis:

H4: potential employees' perception of employers' usage of social networks positively moderates the relationship between image of the employer and potential employees' intention to apply for a job.

Assuming the described relationships, there exist a demand to measure the impact of workplace attractiveness and usage of social networks upon image of employer and then to evaluate if image of employer has impact upon intentions to apply for a job.

Methodology and research methods. Research model shows that attractive workplace communications on social network have impact upon the image of employer and the latter has impact upon intentions to apply for a job position. However, what is not clear is the strength of this impact. Consequently, authors of the manuscript develop a further research postulate to explore this issue in the context of banking.

In order to find out if attractive workplace communications on social networks impact the image of employer (i. e. banks), authors initiated a study examining the attitudes on the job choices of students of Vilnius university (Lithuania). This study took up a quantitative approach. Research is based on commercial banks operating in Lithuania.

Research population consists of students of Vilnius University. Students are suitable for the research of attractive workplace communications on social networks impact upon image of employer because at the moment they are job seekers or are planning to search for a job in the nearest future. Students are current or potential employees for Lithuanian banks. Apart from this, «choosing a relatively homogeneous group of students strengthens the design by avoiding disturbance from possible third variables and helps isolating the relationships under study» (Sivertzen et al., 2013).

Data was collected through a self-administered questionnaire. For the measurement of workplace attractiveness, usage of social media, image of employer and intentions to apply for a job authors of this manuscript decided to use established and reliable measurement scales. The questionnaire contained four scales. The chosen scales were adapted to the context of banking.

The research employed workplace attractiveness scale developed by S. Highhouse et al. (2003). This instrument was chosen because it has already been employed in international study and showed good reliability (Highhouse et al., 2003).

In order to evaluate usage of social networks a 4-item measure was adapted from the one used by C. J. Collins, C. K. Stevens (2002). Original scale was meant to be used in general marketing of 

Intentions to Apply for a Job Position

companies and job vacancies, so the scale was adapted not only to the context of banking, but to the context of social media as well.

The 5-item measures were adapted from the scales used by S. Highhouse et al. (2003) in order to evaluate image of employer and intentions to apply for a job.

Respondents rated each item on a scale from 1 to 5 , where 1 means strong disagreement, 5 strong agreement. Composites were formed by summing the ratings for items associated with every item of the scale. The scales used for the research have been translated from English to Lithuanian for this survey. The translation has been checked for spelling and content.

Particular demographic and professional characteristics might be related to differences in attractiveness or workplace and image of employer. Scientific literature let to distinguish the following characteristics that might be important in the context of the research: gender (Knox and Freeman, 2006; Figurska and Matuska, 2013), age (Figurska and Matuska, 2013), income, employment (Figurska and Matuska, 2013), professional experience (Priyadarshi, 2011). Therefore, the questionnaire contained these demographic and professional characteristics.

A pretest with 5 students was performed in order to adjust and check understanding of the translated scales. Reliability of the scales was examined based on inter-item consistency using Cronbach's alpha (a) coefficient. Cronbach's alpha (a) of scales are presented in Table 1.

Table 1. Scale reliability

\begin{tabular}{|c|c|c|}
\hline Scale & Number of items & Cronbach alpha \\
\hline Workplace attractiveness & 5 & 0.670 \\
\hline Usage of social media & 4 & 0.822 \\
\hline Image of employer & 5 & 0.855 \\
\hline Intentions to apply for a job position & 5 & 0.882 \\
\hline
\end{tabular}

Source: developed by the authors.

Reliability estimates of all scales are all over the threshold value of 0.6 . These estimates indicate adequate reliability.

Authors of the research sent a link to the questionnaire to students of Vilnius university, Lithuania. More than 500 emails and messages in social network «Facebook» were sent. The final sample consisted of 259 students. More than $60 \%$ of respondents were women. The sample consisted of $35.52 \%$ men. In terms of age, there was predominance of students between 21 and $40(71.04 \%)$. $17.76 \%$ of respondents confirmed that they belong to the age interval between 41 and 60 . Only $11.20 \%$ of survey participants were younger than 20 . As for income level, $39.00 \%$ of respondents get $501-1000$ Eur income per month. $23.94 \%$ of respondents stated that their monthly income is less than 500 Eur and 20.08 indicated that their monthly payment is higher than 1001 , but not more than 1500 Eur. The average income of Vilnius university students who participated in the research is 937 Eur. Data of the research shows that $80.31 \%$ of students who filled questionnaires were employed at the moment of the research. It was found out that over $30 \%$ of the sample had less than 3 years of professional experience. It means that majority of sample consisted of inexperienced job seekers. Out of 208 employed students only 1 was employed in a bank at the moment of the research. However, $6.95 \%$ of the sample have worked in banking industry previously. It means that only a small proportion of students are familiar with employment in commercial banks.

The statistical processing of the research data was conducted using SPSS and MS Excel software packages. The significance level was set at $95 \%$. Descriptive statistics were produced for every question of the survey. Chi-Square $(x 2)$ tests were also used. The $x 2$ statistic was treated as significant with a $p$ value bellow 0.05 . 
N. Vilkaite-Vaitone, U. Lukaite. Employer Attractiveness on Social Networks and Organizational Image as Predictors of Intentions to Apply for a Job Position

Results. In order to evaluate workplace attractiveness, usage of social media, image of employer and intention to apply for a job position in Lithuanian commercial banks, mean ratings, standard deviation, minimum and maximum were calculated. Table 2 shows the results obtained for the entire population that was interested in working banking industry. The perception that the chosen bank is attractive as a place for employment had the highest mean score $(M=3.55 ; S D=1.22)$. The second highest score was estimated for the proposition that the chosen bank would be a good place to work $(M=3.26$; $S D=1.29)$. No significant differences exist between workplace attractiveness and gender, age, income, employment, professional experience, choice of the most favourable bank. As for experience in bank, there exist significant differences with workplace attractiveness $(x 2=92.771 ; p=0.049)$; i. e. items of workplace attractiveness are more appreciated by those who have professional experience in banking industry.

Table 2. Mean ratings of research constructs

\begin{tabular}{|c|c|c|c|c|c|c|}
\hline Scales & Items & $\mathbf{N}$ & Minimum & Maximum & Mean & $\begin{array}{c}\text { Std. } \\
\text { Deviation }\end{array}$ \\
\hline \multirow{5}{*}{$\begin{array}{c}\text { Workplace } \\
\text { attractiveness }\end{array}$} & WA1 & 259 & 0 & 5 & 3.26 & 1.29 \\
\hline & WA2 & 259 & 0 & 5 & 2.64 & 1.22 \\
\hline & WA3 & 259 & 0 & 5 & 3.55 & 1.22 \\
\hline & WA4 & 259 & 0 & 5 & 3.00 & 1.42 \\
\hline & WA5 & 259 & 0 & 5 & 3.02 & 1.44 \\
\hline \multirow{4}{*}{$\begin{array}{l}\text { Usage of } \\
\text { social media }\end{array}$} & USM1 & 259 & 0 & 5 & 2.32 & 1.34 \\
\hline & USM2 & 259 & 0 & 5 & 2.36 & 1.41 \\
\hline & USM3 & 259 & 0 & 5 & 2.54 & 1.37 \\
\hline & USM4 & 259 & 0 & 5 & 2.44 & 1.44 \\
\hline \multirow{5}{*}{$\begin{array}{l}\text { Image of } \\
\text { employer }\end{array}$} & $\mathrm{IE} 1$ & 259 & 0 & 5 & 2.98 & 1.47 \\
\hline & IE2 & 259 & 0 & 5 & 3.14 & 1.41 \\
\hline & IE3 & 259 & 0 & 5 & 3.33 & 1.33 \\
\hline & IE4 & 259 & 0 & 5 & 3.00 & 1.26 \\
\hline & IE5 & 259 & 0 & 5 & 2.98 & 1.38 \\
\hline \multirow{5}{*}{$\begin{array}{l}\text { Apply for a job } \\
\text { position }\end{array}$} & AJP1 & 259 & 0 & 5 & 3.12 & 1.39 \\
\hline & AJP2 & 259 & 0 & 5 & 2.96 & 1.42 \\
\hline & AJP3 & 259 & 0 & 5 & 3.16 & 1.45 \\
\hline & AJP4 & 259 & 0 & 5 & 2.96 & 1.46 \\
\hline & AJP5 & 259 & 0 & 5 & 2.87 & 1.57 \\
\hline
\end{tabular}

Source: developed by the authors.

The highest mean score was given to the item that states that profiles of banks' in social network catches ones attention. However, mean ratings of every item were closely to the average (2.50), they all fit into interval from 2.32 to 2.54 . The lowest average score was given to the item about sought advertisings for jobs at banks in social networks. It means that such advertisings are frequently seen; banks do not use the opportunity to advertise as attractive employers on social networks. No significant differences were found between perceptions of usage of social media and gender, age, income, employment, length of professional experience, and professional experience. Significant differences, in turn, were identified between choice of a bank as the most favourable employer and usage of social media ( $x 2=268.946 ; p=0.000$ ).

Mean ratings for the items of image of employer show that the highest average score was given to the proposition that states that the bank probably has an image as being an excellent employer $(M=3.33$; $S D=1.33)$. Quite a high average score was given to the proposition that the bank is reputable $(M=3.14$; 

Intentions to Apply for a Job Position

$S D=1.41)$. The prestige of the bank as a place to work gained the evaluation of 3.00 out of 5.00 . Results of the research have shown that no significant differences exist between image of employer and gender, age, income, employment, and length of professional experience. While differences were identified between professional experience in bank and image of employer $(X 2=103.475 ; p=0.009)$. Those who work in a bank at the moment gave highest score to the image of employer $(M=21.00)$. Students who had previous professional experience in banking industry appointed considerably lower scores $(M=16.00)$. The average score of image of employer of those who had never been working in banking industry was 14.86. Significant differences were also identified between image of employer and choice of a bank as the most favourable employer $(X 2=288.240 ; p=0.000)$.

It was found out that the highest mean score of the construct of intentions to apply for a job position belongs to the proposition «l would accept a job offer from this bank» $(M=3.12 ; S D=1.39)$. No significant differences were found between intentions to apply for a job position and gender, age, income, employment, and length of professional experience. It was identified that significant differences of intentions to apply for a job exist depending on professional experience in bank ( $X 2=108.929 ; p=0.002$ ). Respondents who work in banks at the moment had the highest score to apply for a job position $(M=24.00)$, compared to those who had worked in banks previously $(M=16.39)$ and those who do not have any professional experience in banking industry $(M=14.39)$. Choice of the most favourable bank was also found to determine significant differences in intentions to apply for a job position $(X 2=246.3489$; $p=0.000$ ).

Results indicate correlations between workplace attractiveness, image of employer, usage of social media and intentions to apply for a job position (Table 3).

Table 3. Correlation matrix

\begin{tabular}{|c|c|c|c|c|c|}
\hline Research constructs & Indicator & $\begin{array}{c}\text { Workplace } \\
\text { attractiveness }\end{array}$ & $\begin{array}{l}\text { Image of } \\
\text { employer }\end{array}$ & $\begin{array}{c}\text { Usage of } \\
\text { social media }\end{array}$ & $\begin{array}{l}\text { Intentions to apply } \\
\text { for a job position }\end{array}$ \\
\hline \multirow{2}{*}{$\begin{array}{c}\text { Workplace } \\
\text { attractiveness }\end{array}$} & $r$ & 1.000 & $0.573^{\star *}$ & $0.423^{* *}$ & $0.637^{\star *}$ \\
\hline & $p$ & & 0.000 & 0.000 & 0.000 \\
\hline \multirow{2}{*}{ Image of employer } & $r$ & $0.573^{* *}$ & 1.000 & $0.471^{* *}$ & $0.727^{\star *}$ \\
\hline & $p$ & 0.000 & & 0.000 & 0.000 \\
\hline \multirow{2}{*}{$\begin{array}{l}\text { Usage of social } \\
\text { media }\end{array}$} & $r$ & $0.423^{* *}$ & $0.471^{* *}$ & 1.000 & $0.402^{* *}$ \\
\hline & $p$ & 0.000 & 0.000 & & 0.000 \\
\hline \multirow{2}{*}{$\begin{array}{l}\text { Intentions to apply } \\
\text { for a job position }\end{array}$} & $r$ & $0.637^{* *}$ & $0.727^{* *}$ & $0.402^{* *}$ & 1.000 \\
\hline & $p$ & 0.000 & 0.000 & 0.000 & \\
\hline
\end{tabular}

Source: developed by the authors.

The strongest relationships are those between workplace attractiveness and intentions to apply for a job $(r=0.637 ; p=0.000)$. It means that increase of workplace attractiveness strengthens students' intentions to apply for a job position. Relationships between other constructs were also significant. It means that the more attractive workplace is, the better its usage of social media and image of employer are, and vice versa, better image of employer and better usage of social media is related to a more higher attractiveness of workplace.

Hypothesis 1 predicted a positive relationship between potential employees' perception of workplace attractiveness and the perception of good image of employer. As shown in Table 4, perception of workplace attractiveness was significantly related to the perception of good image of employer. Thus, hypothesis 1 was supported. 
N. Vilkaite-Vaitone, U. Lukaite. Employer Attractiveness on Social Networks and Organizational Image as Predictors of Intentions to Apply for a Job Position

Table 4. Results of regression analysis of workplace attractiveness impact upon image of employer

\begin{tabular}{|c|c|c|c|c|c|c|}
\hline \multirow{2}{*}{ Model } & \multirow{2}{*}{$\boldsymbol{R}^{\mathbf{2}}$} & \multicolumn{2}{|c|}{$\begin{array}{c}\text { Unstandardized } \\
\text { coefficients }\end{array}$} & $\begin{array}{c}\text { Standardized } \\
\text { coefficients }\end{array}$ & \multirow{2}{*}{$\boldsymbol{t}$} & $\boldsymbol{p}$ \\
\cline { 3 - 5 } & & $\mathbf{B}$ & Std. error & Beta & & \\
\hline Constant & 00.329 & 4.253 & 1.056 & & 4.029 & 0.000 \\
\cline { 4 - 7 } & & 0.723 & 0.066 & 0.573 & 11.002 & 0.000 \\
\hline $\begin{array}{c}\text { Workplace } \\
\text { attractiveness }\end{array}$ & & & & & & \\
\hline
\end{tabular}

Source: developed by the authors.

Workplace attractiveness has a positive impact upon image of employer because $p<0.05$. Standardized coefficient $\beta=0.573$. Workplace attractiveness explains $32.9 \%$ of variation of image of employer. It means that workplace attractiveness is a significant factor in explaining the image of employer.

Hypothesis 2 states that potential employees' perception of employers' usage of social networks is positively related with a good image of employer. Table 5 shows that usage of social networks is significantly related to the perception of image of employer. Hence, hypothesis 2 was supported.

Table 5. Results of regression analysis of usage of social networks impact upon image of employer

\begin{tabular}{|c|c|c|c|c|c|c|}
\hline \multirow{2}{*}{ Model } & \multirow{2}{*}{$\boldsymbol{R}^{2}$} & \multicolumn{2}{|c|}{$\begin{array}{c}\text { Unstandardized } \\
\text { coefficients }\end{array}$} & $\begin{array}{c}\text { Standardized } \\
\text { coefficients }\end{array}$ & \multirow{2}{*}{$\boldsymbol{t}$} & $\boldsymbol{p}$ \\
\cline { 3 - 5 } & & $\mathbf{B}$ & Std. error & Beta & 12.640 & 0.000 \\
\hline Constant & 00.471 & 9.281 & 0.734 & & 8.566 & 0.000 \\
\cline { 3 - 5 } $\begin{array}{c}\text { Usage of social } \\
\text { networks }\end{array}$ & & 0.602 & 0.070 & 0.0471 & & \\
\hline
\end{tabular}

Source: developed by the authors.

It can be stated that usage of social networks has a positive impact upon image of employer because $p<0.05$. Standardized coefficient $\beta=0.0471$. Usage of social networks explains $47.1 \%$ of variation of image of employer. Such findings confirm that usage of social networks is a very significant factor in explaining image of employer in case of Lithuanian commercial banking industry.

Hypothesis 3 predicted that good image of employer is positively related with potential employees' intentions to apply for a job. As shown in Table 6, perception of image of employer is positively related with intentions to apply for a job. Thus, such findings let to state that hypothesis 3 was supported.

Table 6. Results of regression analysis of image of employer impact upon potential employees' intentions to apply for a job

\begin{tabular}{|c|c|c|c|c|c|c|}
\hline \multirow{2}{*}{ Model } & \multirow{2}{*}{$\boldsymbol{R}^{\mathbf{2}}$} & \multicolumn{2}{|c|}{ Unstandardized coefficients } & \multirow{2}{*}{$\begin{array}{c}\text { Standardized } \\
\text { coefficients }\end{array}$} & \multirow{2}{*}{$\boldsymbol{t}$} & \multirow{2}{*}{$\boldsymbol{p}$} \\
\cline { 3 - 6 } & & $\mathbf{B}$ & Std. error & Beta & & \\
\hline Constant & 00.727 & 2.919 & 0.738 & & 3.954 & 0.000 \\
\cline { 3 - 7 } $\begin{array}{c}\text { Image of } \\
\text { employer }\end{array}$ & & 0.781 & 0.046 & 0.727 & 16.993 & 0.000 \\
\hline
\end{tabular}

Source: developed by the authors.

Results of the research show that image of employer has a positive impact upon potential employees' intentions to apply for a job because $p<0.05$. Standardized coefficient $\beta=0.727$. Usage of 

Intentions to Apply for a Job Position

social networks explains $72.7 \%$ of variation of image of employer. It shows that other factors explain only $27.3 \%$ of variation of image of employer.

Hypothesis 4 states that potential employees' perception of employers' usage of social networks positively moderates the relationship between image of the employer and potential employees' intention to apply for a job. As shown in Table 7, usage of social media has interaction effect between image of employer and potential employees' intentions to apply for a job, however the effect is negative. Hence, $\mathrm{H} 4$ is not supported in the present study.

Table 7. Results of regression analysis of usage of social media impact upon interaction between image of employer and potential employees' intentions to apply for a job

\begin{tabular}{|c|c|c|c|c|c|c|}
\hline \multirow{2}{*}{ Model } & \multirow{2}{*}{$R^{2}$} & \multicolumn{2}{|c|}{ Unstandardized coefficients } & \multirow{2}{*}{$\begin{array}{c}\begin{array}{c}\text { Standardized } \\
\text { coefficients }\end{array} \\
\text { Beta } \\
\end{array}$} & \multirow[t]{2}{*}{$t$} & \multirow{2}{*}{$p$} \\
\hline & & B & Std. error & & & \\
\hline Constant & \multirow[t]{2}{*}{00.547} & 4.543 & 0.890 & & 5.106 & 0.000 \\
\hline $\begin{array}{l}\text { Image of } \\
\text { employer }\end{array}$ & & 0.697 & 0.052 & 0.649 & 13.303 & 0.000 \\
\hline Moderator & & -0.801 & 0.254 & -0.154 & -3.156 & 0.002 \\
\hline
\end{tabular}

Source: developed by the authors.

To summarize, it can be stated that constructs of workplace attractiveness and image of the employer gained the strongest approval of students who consider their possibilities to be employed in banking industry. It was found that in case of banking industry there exist clear links between workplace attractiveness, usage of social networks and image of an employer. The latter construct is positively related to intentions to apply for a job.

Discussion. Results of the empirical research in the field of attractive workplace communications on social networks impact on image of the employer confirmed that students who are looking for a job in commercial banks have a tendency to behave similarly to consumers in a marketplace. Such a finding suggests commercial banks to present themselves as attractive working places on social networks in order to form a favourable employer's image and encourage job seekers to apply for positions. It means that social networks have a relevant role in forming the image of employer.

Results of the research are undoubtedly relevant for commercial banks operating in Lithuania as they provide banks with useful insights of the factors that determine their image in labour market. Such information give banks a perceptible information of how to become more attractive in labour market with the help of communications on social networks.

Empirical research has identified that students who are working in banking industry possess a better image of a bank as an employer. It means that for banks it is important to formulate not only external image, but internal as well. Internal image might enhance employee willingness to continue employment in the bank and foster employee loyalty.

The research had the following limitations:

1. The context of the research was limited to the sector of commercial banks in Lithuania. It means that results of the research might be inapplicable to find out the trends in other segments of public institutions or businesses.

2. Respondents that took part in the questionnaire survey were students of Vilnius university. These students are the potential labour force for commercial banks operating in Lithuania. Such a choice of respondents lets to presume that results might be inapplicable to find out the trends of viewpoint among members of other social groups. 
3. Research was limited on communication on digital social networks. Authors of this publication understand that originally the concept of social networks has a much broader content, however the research is specified to evaluate attractiveness of communication only in digital social networks.

In the future it would be relevant to research attractive workplace communications impact on the image of other economy sectors (not only banks). It might be useful to gain insights about this impact among members of other social groups or other communication forms.

Conclusions. Analysis of scientific literature in the field of relations between attractive workplace communications and the image of employer has shown that there exist sufficient scientific background to expect a positive impact of workplace attractiveness on the image of employer. Usage of social media is also supposed to have a positive impact on the image. Literature analysis lets to expect relationships between image of employer and potential employees' intentions to apply for a job.

In the first stage, the study examined mean scores of workplace attractiveness, usage of social media, image of employer and intentions to apply for a job position. The study found that constructs of workplace attractiveness and image of the employer gained the strongest approval of students who consider their possibilities to be employed in banking industry. Results of the research have shown that significant differences exist between professional experience in bank and workplace attractiveness. Workplace attractiveness is higher for those who have professional experience in banking industry. Significant differences were identified between choice of a bank as the most favourable employer and usage of social media. Those who work in a bank at the moment gave highest score to the image of employer. Students who had previous professional experience in banking industry appointed considerably lower scores. Significant differences of intentions to apply for a job exist depending on professional experience in bank. Respondents who work in banks at the moment had the highest score to apply for a job position, compared to those who had worked in banks previously and those who do not have any professional experience in banking industry. Choice of the most favourable bank was also found to determine significant differences in intentions to apply for a job position.

Three out of four research hypotheses were confirmed $(\mathrm{H} 1, \mathrm{H} 2, \mathrm{H} 3)$. It means that potential employees' perception of workplace attractiveness is positively related with the perception of good image of employer. Regression model where workplace attractiveness was an independent variable explained of $33 \%$ variance in image of employer, suggesting that attractiveness is a very important variable in explaining image of an employer. It was found that potential employees' perception of employers" usage of social networks is positively related with a good image of employer. Regression model with the usage of social networks as an independent variable explained $47 \%$ of variation. It means that workplace attractiveness together with usage of social networks explain $80 \%$ of variation of image of an employer. The result pointed out that good image of employer is positively related with potential employees' intentions to apply for a job. One of the hypotheses, $\mathrm{H} 4$ was not confirmed. Usage of social media has interaction effect between image of employer and potential employees' intentions to apply for a job, however the effect is negative.

Results of empirical research suggest that job seekers in a labour market behave similarly to consumers in a marketplace. Banks should put efforts in order to present themselves as attractive working places on social networks in order to form a favourable employer's image and encourage job seekers to apply for positions. Results of this study indicate that usage of social networks for the formation of image of employer can be a helpful tool. This is important because there are clear links between workplace attractiveness, usage of social networks and image of an employer. The latter construct is positively related to intentions to apply for a job.

Author Contributions. Conceptualization, N. V. V. and U. L.; methodology, N. V. V. and U. L.; software, N. V. V.; validation, U. L.; formal analysis, N. V. V. and U. L.; investigation, N. V. V. and U. L.; 
N. Vilkaite-Vaitone, U. Lukaite. Employer Attractiveness on Social Networks and Organizational Image as Predictors of Intentions to Apply for a Job Position

resources, N.V.V. and U.L.; data curation, N.V.V. and U.L.; writing-original draft preparation, N. V. V. and U. L.; writing-review and editing, N. V. V.; visualization, U. L.; supervision, N. V. V.

\section{References}

Aizen I. (1991). The theory of planned behavior. Organizational Behavior and Human Decision Processes, 50(2), 179-211. Ajzen I. (2002). Perceived behavioural control, self-efficacy, locus of control, and the theory of planned behaviour. Journal of Applied Social Psychology, 32(4), 665-683.

Berthon P., Ewing M., Hah L. L. (2005). Captivating company: dimensions of attractiveness in employer branding. International Journal of Advertising, 24, 151-172.

Bondarouk T., Ruel H. J. M., Weekhout W. (2012). Employer branding and its effect on organizational attractiveness via the World Wide Web: results of quantitative and qualitative studies combined. Proceedings of the 4th International e-HRM Academic Conference on Innovation, Creativity and e-HRM.

Cable D. M., \& Yu K. Y. T. (2006). Managing job seekers' organizational image beliefs: The role of media richness and media credibility. Journal of Applied Psychology, 91, 828-840.

Caligiuri P., Phillips J., Lazarova M., Tarique I., Burgi P. (2001). The theory of met expectations applied to expatriate adjustment: the role of crosscultural training. The International Journal of Human Resource Management, 12, 357-372.

Celani A., Singh P. (2011). Signalling theory and applicant attraction outcomes. Personnel Review, 40(2), 222-238.

Collins C. J., Stevens, C. K. (2002). The relationship between early recruitment-related activities and the application decisions of new labor-market entrants: a brand equity approach to recruitment. Journal of Applied Psychology, 87, 1121-1133.

Correa T., Hinsley A. W., de Zúniga H. G. (2010). Who interacts on the web? The intersection of users' personality and social media use. Computers in Human Behavior, 26(2), 247-253.

Cretu A. E., Brodie, R. J. (2007). The influence of brand image and company reputation where manufacturers market to small firms: A customer value perspective. Industrial Marketing Management, 36(2), 230-240.

Cross M. (2014). Employment and Social Media. Social Media Security, 45-70.

Edwards, M. R. (2009). An integrative review of employer branding and OB theory. Personnel Review, 39(1), 5-23

Eger L., Micik M., Gangur M., Rehor P. (2019). Employer branding: exploring attractiveness dimensions in a multicultural context. Technological and Economic Development of Economy, 25(3), 519-541.

Figurska I., Matuska E. (2013). Employer branding as a human resources management strategy. Human Resources Management \& Ergonomics, 7(2), 35-51.

Gomes D., Neves J. (2011). Organizational attractiveness and prospective applicants' intentions to apply. Personnel Review, 40(6), 684-699

Highhouse S., Lievens F., Sinar, E. F. (2003). Measuring attraction to organizations. Educational and Psychological Measurement, 63(6), 986-1001.

Jiang T. T., lles P. (2011). Employer-brand equity, organizational attractiveness and talent management in the Zhejiang private sector, China. Journal of Technology Management in China, 6(1), 97-110.

Kissel P., Buttgen M. (2015). Using social media to communicate employer brand identity: the impact on corporate image and employer attractiveness. Journal of Brand Management, 22(9), 755-777.

Knox S., Freeman C. (2006). Measuring and managing employer brand image in the service industry. Journal of Marketing Management, 22, 695-716.

Lievens F., Hoye G. V., Anseel F. (2007). Organizational identity and employer image: towards a unifying framework. British Journal of Management, $18,45-59$.

Marcus B., Schuler H. (2004). Antecedents of counterproductive behavior at work: a general perspective. Journal of Applied Psychology, 89(4), 647-660.

Mathieson K. (1991). Predicting user intentions: comparing the technology acceptance model with the theory of planned behaviour. Information Systems Research 2(3), 173-239.

Melewar T. C., Karaosmanoglu E. (2006). Seven dimensions of corporate identity: a categorisation from the practitioners perspectives. European Journal of Marketing, 40(7/8), 846-869.

Moroko L., Uncles M. D. (2008). Characteristics of successful employer brands. Journal of Brand Management, 16(3), 160-175

Pingle S. S., Sharma A. (2013). External employer attractiveness: a study of management students in India. Journal of Contemporary Management Research, 7(1), 78-95.

Priyadarhini C., Kumar Y. L. N., Jha R. R. (2017). Employer attractiveness through social media: a phenomenological study. The Qualitative Report, 22(4), 969-983

Priyadarshi P. (2011). Employer brand image as predictor of employee satisfaction, affective commitment \& turnover. The Indian Journal of Industrial Relations, 46(3), 50-522. 
N. Vilkaite-Vaitone, U. Lukaite. Employer Attractiveness on Social Networks and Organizational Image as Predictors of Intentions to Apply for a Job Position

Reis G. G., Braga B. M. (2016). Employer attractiveness from a generational perspective: implications for employer branding. Revista de Administracao, 51(1), 103-116.

Robertson A., Arachchige B. (2013). Employer attractiveness: Comparative perceptions of undergraduate and postgraduate students. Sri Lankan Journal of Human Resource Management, 4(1), 33-48.

Sivertzen A. M., Nilsen E. R., Olafsen A. H. (2013). Employer branding: employer attractiveness and the use of social media. Journal of Product \& Brand Management, 22(7), 473-483.

Tuzuner V. L., Yuksel C. A. (2009). Segmenting potential employees according to firms employer attractiveness dimensions in the employer branding concept. Journal of Academic Research in Economics, 1(1), 46-61.

Нерінга Вілкаіте-Ваітоне, D.SC., Вільнюський технічний університет імені Гедимінаса (Литва);

Унге Лукаіте, Університет Вільнюса (Литва).

Імідж компанії в соціальних мережах та його вплив на рекрутинг персоналу

у статті систематизовано аргументи та контраргументи у межах наукових дискусій щодо привабливості роботодавия у соціальних мережах, впливу іміджу організації на активність подачі заявок на працевлаштування в банку. Головною метою дослідження є теоретичне та емпіричне оиінювання впливу ефекктивності комунікацій банку у соціальних мережах та його іміджу як роботодавия на наміри подати заяву на працевлаштування. На основі систематизації літературних джерел та підходів до вирішення досліджуваної проблеми зроблено висновок про наявність позитивного впливу привабливості робочого місия на імідж роботодавия. Автори припускають, що використання соціальних мереж має позитивний ефрект на імідж компанії, тоді як імідж може бути прогнозуючим фактором намірів особи подати заяву на працевлаштування. Актуальність дослідження полягає у тому, що соиіальні мережі мають істотний вплив на імідж роботодавия як підвищити, так і знищити. Авторами зазначено, що роль комунікацій банків у соиіальних мережах значно впливає на побудову іміджу банку як роботодавия. У статті на основі емпіричних результатів обгрунтовано, що поведінка осіб, які шукають роботу на ринку праці $є$ аналогічною споживчому ринку. При цьому підгрунтям дослідження стали результати анкетування студентів у Литві. Таким чином, банки повинні збільшити зусилля у побудові позитивного образу для того, щоб презентувати себе як привабливого роботодавия у соціальних мережах та заохочувати осіб, які шукають роботу, до подання заяви на певну посаду. Так, отримані результати дослідження свідчать про те, що використання соціальних мереж з метою формування іміджу роботодавия $є$ перспективним інструментом. У свою чергу, враховуючи позитивний зв'язок між привабливістю проаналізованих факторів та іміджом роботодавия, роботодавцю необхідно використовувати соціальні мережі з метою залучення потенційних працівників. Отримані результати дослідження можуть бути корисними для комериійних банків, надаючи їм інформацію щодо факторів, які вливають на їх імідж на ринку праці.

Ключові слова: привабливість роботодавця, брендинг роботодавця, соціальні мережі, імідж організації, наміри подання заяви про прийняття на роботу, банківська система.

Manuscript received: 03.08.2019

(C) The author(s) 2019. This article is published with open access at Sumy State University. 